\title{
Reduced in vitro erythroid progenitor cell growth in bronchial cancer
}

\author{
GILLIAN S MASTERS, ${ }^{*}$ P BAINES, ${ }^{*}$ R BAILEY-WOOD, ${ }^{*}$ T GORVETT,* \\ T LITTLEWOOD, $\dagger$ P BENTLEY, $\dagger$ HELEN PARRY-JONES $\ddagger$ A JACOBS*
}

From the *Department of Haematology, University of Wales College of Medicine, Cardiff, the $\dagger$ Department of Haematology, Llandough Hospital, Cardiff, and the $\ddagger$ Blood Transfusion Centre, Rhydlafar, Cardiff, Wales

SUMMARY Peripheral blood and bone marrow were studied in 21 men with disseminated untreated bronchial cancer in an attempt to define abnormalities of erythropoiesis associated with the development of anaemia. Haemoglobin concentration at or below $13 \mathrm{~g} / \mathrm{dl}$ was present in 13 cases. Marrow morphology was normal in all cases except one, in which small numbers of tumour cells were found. Clonal assay of erythroid progenitors showed a significant decrease in the number of BFU-E $(p=0.03)$ and CFU-E $(p=0.01)$ compared with cultures from normal marrow (12 subjects). The growth of granulocyte and macrophage progenitors (GM-CFCs) was similar in patients with bronchial cancer and normal subjects. When normal marrow was incubated in the presence of serum from bronchial cancer patients, no inhibitory factors could be detected either for BFU-E or CFU-E growth.

In all patients circulating T8 numbers were significantly raised $(p=0.0002)$. Consequently, the median T4:T8 ratio in blood was 1.2 , and this was significantly lower than the ratio of 1.7 found in 20 normal subjects $(p=0.036)$. In 18 patients the bone marrow T4:T8 ratio of $1 \cdot 1$ was significantly lower than the ratio of 2.9 found in seven normal subjects $(p=0.04)$. Total blood white cell counts, neutrophils, and monocyte numbers were also increased $(p=0.0001 ; p=0.0001 ; p=0.002)$.

There is, as yet, no satisfactory explanation for anaemia in chronic disease. Ineffective erythropoiesis does not seem to be responsible for the mild anaemias seen in Hodgkin's disease, ${ }^{1}$ myelomatosis, ${ }^{2}$ and rheumatoid arthritis, ${ }^{3}$ and this distinguishes the condition from iron deficiency anaemia. Red cell life span is not severely shortened, but the erythropoietic response to the onset of anaemia seems to be blunted. ${ }^{3}$ Some workers have attributed this to a failure of erythropoietin production, ${ }^{4-6}$ although this remains controversial. $^{7-9}$ Circulating inactivators of erythroprotein have been implicated in the anaemia of chronic renal failure. ${ }^{10}$ This could explain why sera from patients with bronchial cancer and rheumatoid arthritis were reported to inhibit in vitro erythropoiesis, ${ }^{11} 12$ although it seems increasingly likely that failure of erythroid cell production, in vivo and in vitro, is caused by abnormalities in other cell populations which regulate erythroid progenitor cells. Thus monocytes support the in vitro proliferation and differentiation of erythroid colony forming cells in the presence of sera from non-anaemic, but not from

Accepted for publication 30 June 1986 anaemic, donors with rheumatoid arthritis. ${ }^{12}$ Macrophages from anaemic patients with fungal infection inhibit the proliferation of erythroid colony forming cells, whereas they stimulate their development after the infection has been eliminated, ${ }^{13}$ and inhibitors of erythropoiesis present in chronic renal failure sera act indirectly by preventing $\mathrm{T}$ cells, monocytes, and macrophages from elaborating factors which support in vitro growth of erythroid colony forming cells. ${ }^{14}$ Furthermore, quantitative and qualitative changes in $T$ cell subsets have been noted in the anaemia of acquired immune deficiency syndrome (AIDS), ${ }^{15} 16$ myelodysplastic syndromes, ${ }^{17}$ and aplastic anaemia ${ }^{18}$ and, in the latter two conditions, are associated with moderate to severe depression of numbers of erythroid colony forming cells in the marrow.

We investigated the associations between progenitor cell numbers and serum inhibitory factors, neutrophils, monocytes and $T$ cell subsets in the anaemia of lung cancer.

\section{Material and methods}

Marrow aspirates and blood samples were taken from 
21 newly diagnosed male patients with disseminated bronchial cancer (age range 51-78 years). These comprised 17 small cell carcinomas, one adenocarcinoma, and three squamous cell carcinomas. Normal marrow was obtained from male patients of similar age (50-79 years) undergoing cardiac surgery or total hip replacement. Normal blood was taken from age matched male controls. A pool of AB serum was prepared from healthy donors. Fully informed consent was obtained from all subjects.

\section{SERA}

Both the control pooled $\mathrm{AB}$ serum preparation and individual bronchial cancer sera were heat inactivated at $56^{\circ} \mathrm{C}$ for 30 minutes and were subsequently filtered $(0.45 \mu \mathrm{m})$ and stored at $-20^{\circ} \mathrm{C}$. On thawing, sera were refiltered $(0.45 \mu \mathrm{m})$ to remove aggregates before being added to culture.

\section{BONE MARROW}

Marrow samples were collected in $10 \mathrm{ml}$ Eagle's medium (Flow Laboratories) containing 2\% heat inactivated, filtre sterilised fetal calf serum and 15 $\mathrm{U} / \mathrm{ml}$ preservative free heparin at $4^{\circ} \mathrm{C}$. The cells were immediately centrifuged at $500 \mathrm{~g}$ for 10 minutes, the supernatant discarded, and the pellet resuspended in $5 \mathrm{ml}$ fetal calf serum. Bone marrow granules were broken down by aspiration through a 25 gauge needle. Nucleated cells were separated by centrifugation on Ficoll-Hypaque (Pharmacia) at $400 \mathrm{~g}$ for 30 minutes, the interface layer nucleated cells recovered and washed twice with Hepes-buffered Eagle's medium at $\mathrm{pH} 7 \cdot 4$.

ENUMERATION OF CELL POPULATIONS IN UNFRACTIONATED BLOOD AND MARROW Blood populations were enumerated on a Hematrak differential cell counter (Becton Dickinson) and marrow populations by visual differential counts on Wright-Giemsa stained films.

ENUMERATION OF BLOOD AND MARROW OKT4, OKT8, AND MO2 POPULATIONS IN

MONONUCLEAR CELL FRACTIONS

Cell aliquots $\left(2 \times 10^{6}\right.$ cells $)$ were incubated for 30 minutes at $4^{\circ} \mathrm{C}$ with $5 \mu \mathrm{l}$ of monoclonal antibody OKT4, OKT8 (Ortho Diagnostics), or MO2 (Coulter Clone Ltd). After two washes in phosphate buffered saline (PBS), 2\% bovine serum albumin (BSA, Sigma Diagnostics), and $0.02 \%$ sodium azide cells were further incubated with $5 \mu$ l of fluorescein isothiocyanatelabelled rabbit antimouse Ig (Dako Ltd; F.313), or fluorescein isothiocyanate-labelled goat antimouse Ig (Hybritech), for 30 minutes at $4^{\circ} \mathrm{C}$. After two further washes in PBS + BSA + azide cells were fixed in $2 \%$ paraformaldehyde.
Surface fluorescence was excited at $488 \mathrm{~nm}$ and emission measured at 520-540 $\mathrm{nm}$. Each preparation was counted at 500 cells/second, and a total of $10^{4}$ cells were counted using a FACS III (Becton Dickinson) with gates set to encompass all mononuclear cells.

\section{CELL CULTURE}

Erythroid colony forming cells

Interface mononuclear cells from the Ficoll procedure were cultured by a modification of the technique described by Iscove et al, ${ }^{19}$ in which $2 \times 10^{5}$ nucleated cells $/ \mathrm{ml}$ were cultured in $\alpha$ medium (Flow) containing $0.8 \%$ methylcellulose (Dow, A4M Premium), $2 \cdot 1 \mathrm{~g} / 1$ bicarbonate (Wellcome), $10^{-4} \mathrm{M}$ $\beta$-mercaptoethanol (BDH), $10^{-7} \mathrm{M}$ sodium selenite (BDH), $10 \mathrm{mg} / 1$ vitamin E (Eastman), $10 \mathrm{mg} / 1$ ribonucleosides and deoxyribonucleosides, $100 \%$ saturated human transferrin (Behringwerke, 10-20 $\mu \mathrm{M}$ ), antibiotic and antimycotic solution (Gibco), and 1.0 $\mathrm{U} / \mathrm{ml}$ anaemic sheep erythropoietin (Step III, Connaught). Pooled normal human AB serum (33\% v/v) was added to obtain the final culture mix. Triplicate cultures were incubated at $37^{\circ} \mathrm{C}$ in air with $5 \%$ carbon dioxide in a fully humidified incubator. Colony forming units-erythroid (CFU-E) were scored after seven days and burst forming units-erythroid (BFUE) after 14 days.

Granulocyte-macrophage colony forming cells (GMCFCs)

Interface mononuclear cells were cultured, as previously described ${ }^{20}$ in duplicate in $35 \mathrm{~mm}$ Petri dishes at a concentration of $2 \times 10^{5}$ cells $/ \mathrm{ml}$ of $\alpha$ medium (Gibco Europe Ltd) containing $15 \% \mathrm{v} / \mathrm{v}$ of newborn calf serum (special Bobby calf serum, Gibco Europe Ltd) and $0.3 \%$ of agar, and supplemented with $10 \%$ $\mathrm{v} / \mathrm{v}$ dialysed human placental conditioned medium (HPCM) as a source of GM-CSF. Human placental conditioned medium was prepared after the method of Burgess. ${ }^{21}$ GM-CFCs were scored after seven and 14 days of culture at $37^{\circ} \mathrm{C}$ in air with $5 \%$ carbon dioxide in a humidified incubator.

\section{TESTS FOR SERA INHIBITORY ACTIVITY}

Erythroid colony forming cells from group $O$ rhesus positive donor marrows were cultured under limiting serum conditions ( $25 \%$ pooled, control AB serum). Individual BC sera and some normal control (nonanaemic) sera were added at $10 \%$ of final culture volume, bringing the final serum concentration to $35 \%$.

\section{STATISTICAL ANALYSES}

Non-parametric statistical analyses were appled to the data to minimise the effect of outlying values. Significance was demonstrated by the Mann-Whitney test and correlations by Spearman rank techniques. ${ }^{22}$ 


\section{Results}

HAEMATOLOGICAL DATA ON PATIENTS WITH BRONCHIAL CANCER (TABLE 1)

Taking the bronchial cancer group as a whole, haemoglobin concentrations, serum iron, and total iron binding capacity were reduced, and serum ferritin increased compared with normal control values. Of 21 patients with bronchial cancer, 13 were anaemic (haemoglobin of $13 \mathrm{~g} / \mathrm{dl}$ or less). Per cent transferrin saturation, per cent erythroblasts, and dyserythropoiesis were within the normal range.

\section{WHITE BLOOD CELL, LYMPHOCYTE, AND} MONOCYTE POPULATIONS IN BLOOD AND MARROW OF PATIENTS WITH BRONCHIAL CANCER

Myeloid and monocyte cell numbers were significantly increased in patients' blood but lymphocyte numbers were unchanged (table 2). Total circulating T4 numbers were significantly increased ( $\mathrm{p}=$ 0.046 ) but less so than T8 lymphocytes, which caused a reduction in the $\mathrm{T} 4: \mathrm{T} 8$ ratio (table 3 ).

In the Ficoll interface fraction prepared from marrow of patients with bronchial cancer per cent T4 values were unchanged and per cent T8 cells showed a significant increase (at the $5 \%$ level of probability), which would explain the significantly depressed T4:T8 ratio (table 3 ). The proportion of monocytes in marrow of patients with bronchial cancer (as measured by MO2 staining) was unchanged.
PROGENITOR CELL NUMBERS IN MARROW OF PATIENTS WITH BRONCHIAL CANCER

Both CFU-E and BFU-E numbers were significantly reduced compared with numbers in cultures of normal marrow (table 4), although GM-CFC numbers were unchanged. When patients with bronchial cancer were separated into anaemic and non-anaemic groups, CFU-E numbes were reduced only $(\mathrm{p}=$ 0.009) in non-anaemic patients. BFU-E numbers in the separated anaemic and non-anaemic groups were not significantly different from normal values. There was no correlation between haemoglobin concentration and CFU-E and BFU-E numbers in patients with bronchial cancer $(r=-0.053,+0.150$ respectively; $p>0 \cdot 1$ ).

\section{SERUM INHIBITORY ACTIVITY}

The figure illustrates the effect of adding $10 \%$ of 19 individual bronchial cancer sera to erythroid cultures of normal marrow containing $25 \%$ control pooled AB serum. A batch of 10 bronchial cancer sera were tested in one experiment and a batch of another nine in a second experiment. Colony growth in cultures containing $25 \%$ AB serum $+10 \%$ bronchial cancer serum was compared with growth in cultures containing $25 \%$ and $35 \% \mathrm{AB}$ serum. Five bronchial cancer sera increased CFU-E numbers and seven sera increased BFU-E numbers to a greater degree than $35 \%$ pooled AB serum and were, therefore, "strongly supportive" of erythroid colony forming cell growth. One serum reduced BFU-E numbers to a level below

Table 1 Haematological data on 21 patients with bronchial cancer

\begin{tabular}{|c|c|c|c|c|c|c|c|}
\hline Patients & $\begin{array}{l}\text { Haemoglobin } \\
(g / d l)\end{array}$ & $\begin{array}{l}\text { Serum ferritin } \\
(\mu \mathrm{mol} / \mathrm{l})\end{array}$ & $\begin{array}{l}\text { Serum iron } \\
(\mu \mathrm{mol} / \mathrm{l})\end{array}$ & $\begin{array}{l}\text { Total iron } \\
\text { binding } \\
\text { capacity } \\
\text { (rmol/l) }\end{array}$ & $\begin{array}{l}\text { Transferrin } \\
\text { saturation (\%) }\end{array}$ & $\begin{array}{l}\text { Erythroblasts } \\
(\%)\end{array}$ & $\begin{array}{l}\text { Dyserythropoiesis } \\
(\%)\end{array}$ \\
\hline $\begin{array}{l}\text { Mean (SD) } \\
\text { Range }\end{array}$ & $\begin{array}{r}12(2) \\
7-15\end{array}$ & $\begin{array}{r}531(564) \\
20-2093\end{array}$ & $\begin{array}{l}9(3) \\
4-14\end{array}$ & $\begin{array}{l}45(13) \\
23-66\end{array}$ & $\begin{array}{l}22(7) \\
11-35\end{array}$ & $\begin{array}{r}15(6) \\
7-35\end{array}$ & $\begin{array}{l}1(1) \\
0-4\end{array}$ \\
\hline $\begin{array}{l}\text { Normal mean }(\mathrm{n}=20) \\
\text { Range }\end{array}$ & $\begin{array}{l}14 \cdot 4(1 \cdot 4) \\
13-18\end{array}$ & $\begin{array}{l}93(98) \\
15-300\end{array}$ & $\begin{array}{l}19(8) \\
12-30\end{array}$ & $\begin{array}{l}67(11) \\
45-70\end{array}$ & $\begin{array}{l}27(12) \\
13-49\end{array}$ & $2-20$ & $0-10$ \\
\hline $\mathrm{p}$ value & $>0.001$ & 0.01 & $>0.01$ & $>0.01$ & $>0.1$ & & \\
\hline
\end{tabular}

Table 2 Enumeration of cell populations in unseparated blood of patients studied

\begin{tabular}{|c|c|c|c|c|c|c|c|}
\hline & \multicolumn{3}{|c|}{ Patients with bronchial cancer $(n=21)$} & \multicolumn{3}{|c|}{ Normal donors $(n=20)$} & \multirow[b]{2}{*}{ p value } \\
\hline & Median & Mean & Range & Median & Mean & Range & \\
\hline \multirow{4}{*}{$\begin{array}{l}\text { White cell count } \\
\left(10^{-9} / 1\right) \\
\text { Total polymorphs } \\
\left(\times 10^{-9} / 1\right) \\
\text { Total lymphocytes } \\
\left(\times 10^{-9} / 1\right) \\
\text { Total monocytes } \\
\left(\times 10^{-9} / 1\right)\end{array}$} & 9.9 & $12 \cdot 3$ & $7 \cdot 4-40 \cdot 8$ & $6 \cdot 4$ & 6.5 & $3.9-8.9$ & $<0.0001$ \\
\hline & $6 \cdot 6$ & $9 \cdot 1$ & $4 \cdot 3-37$ & $3 \cdot 7$ & $3 \cdot 8$ & $1 \cdot 8-6 \cdot 1$ & 0.0001 \\
\hline & $2 \cdot 0$ & $2 \cdot 3$ & $0.7-4.3$ & $2 \cdot 1$ & $2 \cdot 0$ & $1 \cdot 3-3 \cdot 3$ & 0.80 \\
\hline & 0.59 & 0.68 & $0.2-1 \cdot 6$ & 0.31 & 0.35 & $0.08-0.67$ & 0.002 \\
\hline
\end{tabular}


Table 3 Enumeration of $T$ lymphocyte and monocyte subsets in mononuclear fractions prepared from normal and bronchial cancer blood and marrow

\begin{tabular}{|c|c|c|c|c|c|c|c|c|}
\hline & & \multicolumn{3}{|c|}{ Patients with bronchial cancer } & \multicolumn{3}{|c|}{ Normal donors } & \multirow[b]{2}{*}{ p value } \\
\hline & & Median & Mean & Range & Median & Mean & Range & \\
\hline $\begin{array}{l}\text { Blood from: } \\
21 \text { patients } \\
\text { with bronchial } \\
\text { cancer and } 20 \\
\text { normal donors }\end{array}$ & $\left\{\begin{array}{l}\% \mathrm{~T} 4 \\
\% \mathrm{~T} 8 \\
\text { Total T4 }\left(\times 10^{-9} / 1\right) \\
\text { Total T8 }\left(\times 10^{-9} / 1\right) \\
\text { T4:T8 ratio }\end{array}\right.$ & $\begin{array}{l}37 \\
29 \\
1 \cdot 0 \\
0.80 \\
1 \cdot 2\end{array}$ & $\begin{array}{l}38 \\
30 \\
1 \cdot 1 \\
0.88 \\
1.4\end{array}$ & $\begin{array}{l}20-60 \\
15-46 \\
0 \cdot 6-2 \cdot 1 \\
0 \cdot 4-2 \cdot 5 \\
0 \cdot 8-2 \cdot 6\end{array}$ & $\begin{array}{l}41 \\
24 \\
0 \cdot 80 \\
0 \cdot 36 \\
1 \cdot 7\end{array}$ & $\begin{array}{l}39 \\
23 \\
0.79 \\
0.47 \\
1.9\end{array}$ & $\begin{array}{l}19-56 \\
13-41 \\
0 \cdot 3-1 \cdot 3 \\
0 \cdot 2-0.9 \\
0 \cdot 5-3 \cdot 5\end{array}$ & $\begin{array}{l}0.48 \\
0.026 \\
0.046 \\
0.0002 \\
0.036\end{array}$ \\
\hline $\begin{array}{l}\text { Marrow from: } \\
18 \text { patients with } \\
\text { bronchial cancer } \\
\text { and seven } \\
\text { normal donors }\end{array}$ & $\left\{\begin{array}{l}\% \mathrm{~T} 4 \\
\% \mathrm{~T} 8 \\
\mathrm{T4} 4 \mathrm{~T} 8 \\
\% \mathrm{MO} 2^{*}\end{array}\right.$ & $\begin{array}{l}17 \\
15 \\
1 \cdot 1 \\
5 \cdot 0\end{array}$ & $\begin{array}{l}18 \\
16 \\
1 \cdot 7 \\
6 \cdot 1\end{array}$ & $\begin{array}{l}3-33 \\
3-36 \\
0 \cdot 3-10 \\
0-15\end{array}$ & $\begin{array}{l}16 \\
6 \cdot 0 \\
2 \cdot 9 \\
11\end{array}$ & $\begin{array}{c}16 \\
9 \cdot 0 \\
3 \cdot 5 \\
13\end{array}$ & $\begin{array}{l}8-25 \\
2-27 \\
0 \cdot 4-7 \cdot 4 \\
2 \cdot 4-38\end{array}$ & $\begin{array}{l}0.63 \\
0.046 \\
0.04 \\
0.25\end{array}$ \\
\hline
\end{tabular}

*Monocytes estimated by MO2 staining.

Table 4 Progenitor cell growth in cultures of bronchial cancer marrow

\begin{tabular}{|c|c|c|c|c|c|c|c|c|}
\hline \multirow{3}{*}{\multicolumn{2}{|c|}{ Progenitor type }} & \multicolumn{6}{|c|}{ Progenitors per $10^{5}$ mononuclear cells } & \multirow[b]{3}{*}{$p$ value } \\
\hline & & \multicolumn{3}{|c|}{ Patients with bronchial cancer } & \multicolumn{3}{|c|}{ Normal donors } & \\
\hline & & Median & Mean & Range & Median & Mean & Range & \\
\hline $\begin{array}{l}\text { Day } 7 \\
\text { Day } 14\end{array}$ & $\begin{array}{l}\text { CFU-E } \\
\text { BFU-E } \\
\text { GM-CFC } \\
\text { GM-CFC }\end{array}$ & $\begin{array}{c}42(\mathrm{n}=21) \\
7(\mathrm{n}=21) \\
76(\mathrm{n}=8) \\
27(\mathrm{n}=8)\end{array}$ & $\begin{array}{l}63 \\
17 \\
83 \\
31\end{array}$ & $\begin{array}{c}0-230 \\
0-107 \\
15-214 \\
12-67\end{array}$ & $\begin{array}{r}157(\mathrm{n}=12) \\
26(\mathrm{n}=14) \\
102(\mathrm{n}=15) \\
63(\mathrm{n}=15)\end{array}$ & $\begin{array}{r}165 \\
29 \\
117 \\
59\end{array}$ & $\begin{array}{c}15-485 \\
0-65 \\
62-184 \\
8-118\end{array}$ & $\begin{array}{l}0.01 \\
0.03 \\
0.2 \\
0.1\end{array}$ \\
\hline
\end{tabular}

that observed in cultures supplemented with $25 \% \mathrm{AB}$ serum - that is, was inhibitory to erythroid colony forming cell growth. Most bronchial cancer sera were "weakly supportive" and increased erythroid colony forming cell numbers, but to a lesser extent than $35 \%$ pooled $\mathrm{AB}$ serum.

\section{Discussion}

In this paper we have reported measurements of marrow and blood functions that might be related to erythropoietic failure in patients with bronchial cancer. Decreased serum iron concentration and total iron binding capacity and increased serum ferritin are all characteristic of the anaemia of chronic disease, ${ }^{3112324}$ as is a rise in blood neutrophils. ${ }^{2425}$ Neutrophils contain lactoferrin, ${ }^{26}$ which, if released in large quantities during neutrophilia, might both depress serum iron and restrict iron supply to maturing erythroid cells. ${ }^{24} 25$ It seems unlikely that these mechanisms could have been responsible for the anaemia in our patients, as they would have caused iron deficient erythropoiesis with obvious ineffective red cell formation, yet ineffective erythropoiesis does not seem to be a contributory factor in anaemia in chronic disease. ${ }^{13}$ In any case there was no correlation between blood neutrophils and serum iron concentration $(r=-0.461 ; 0.05<p<0.1)$ in our patients.

Monocytes were also increased in the blood of patients with bronchial cancer, but, as for neutrophils, their numbers were not related to the degree of anaemia, and monocyte numbers in the marrows of these patients were similar to normal. The changes in lymphocyte subsets in our patients also deserve comment. The decreased T4:T8 ratio is largely the result of increases in T8 cells in both blood and marrow. In marrow the T4:T8 ratio showed a negative correlation with the number of blood neutrophils $(r=$ $-0.525 ; p<0.05$ ), but there was no obvious explanation for this.

A reduced T4:T8 ratio has been reported in anaemias associated with AIDS $^{1516}$ and myelodysplasia, ${ }^{17}$ and an increased marrow $\mathrm{T} 8 \mathrm{lym}$ phocyte burden has been reported to be responsible for the suppression of erythropoiesis in aplastic anaemia. ${ }^{18}$ Lymphocyte function has been shown to be changed both in bronchial cancer ${ }^{27} 28$ and rheumatoid arthritis, ${ }^{29}$ although blood T lymphocytes from patients with rheumatoid arthritis stimu- 

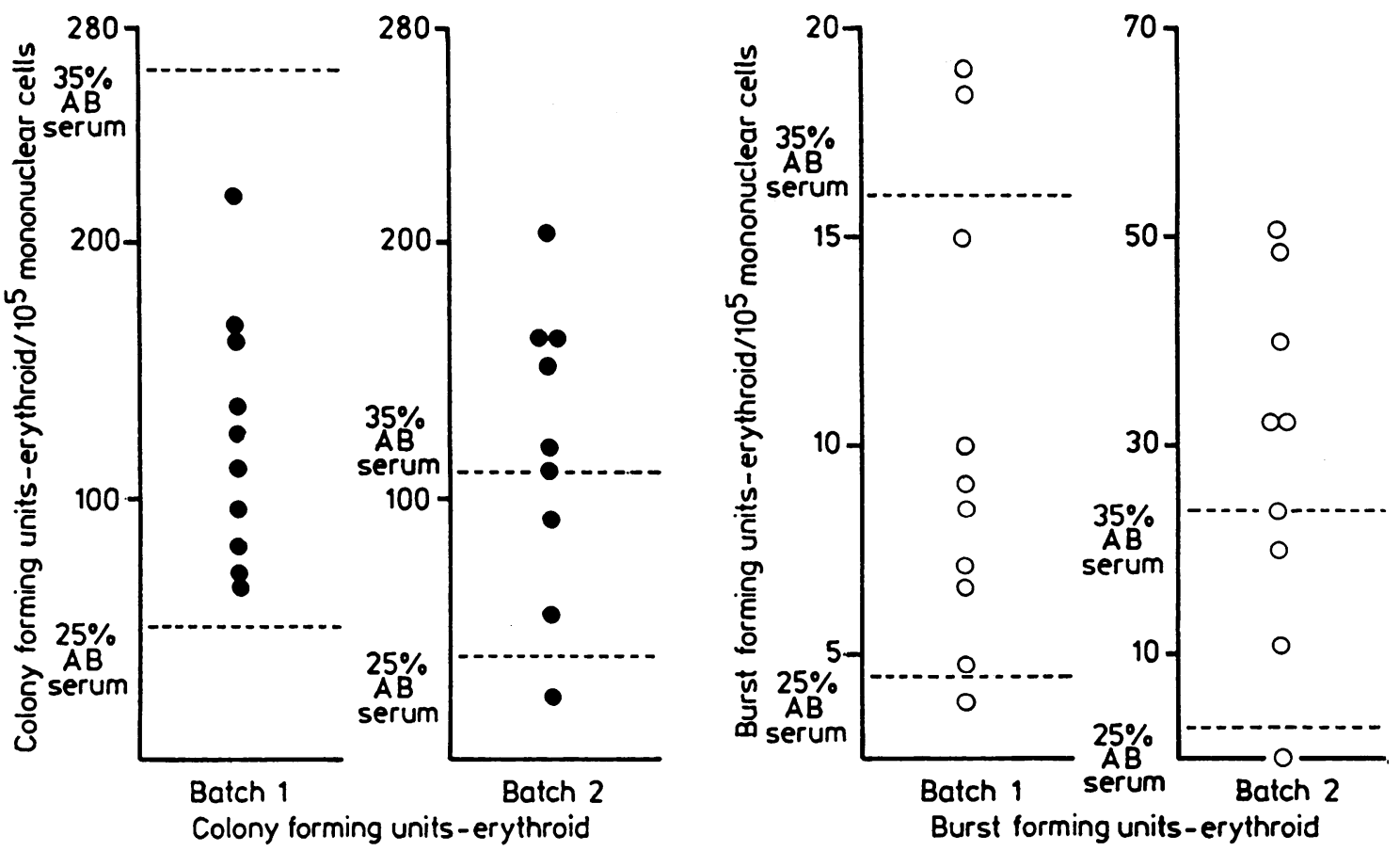

Figure One of two similar experiments. Effect of adding $10 \%$ bronchial cancer serum or $10 \%$ pooled normal AB serum to cultures of normal marrow already containing $25 \%$ AB serum. Ten bronchial cancer sera (batch 1) were tested in one experiment and another nine bronchial cancer sera (batch 2) were tested in second separate experiment. - $-C F U-E ; O-B F U-E$ numbers $/ 10^{5}$ mononuclear cells; - - - , colony numbers in cultures supplemented with $25 \%$ and $35 \%$ AB serum.

lated in vitro erythropoiesis to the same degree as did T lymphocytes from normal donors. ${ }^{12} 30$ In our patients there were no correlations between lymphocyte subset numbers and haemoglobin concentration, so the importance of the changes in these populations to the aetiology of anaemia in bronchial cancer remains unclear.

The perturbations in neutrophil, monocyte, and lymphocyte populations did not correlate with the reduction in erythroid progenitors in bronchial cancer marrows. It seemed plausible that the increased demand for mature neutrophils in patients with bronchial cancer might be met by increasing GM-CFCs at the expense of erythroid colony forming cell production. $^{25}$ GM-CFC numbers, however, were not raised in our patients, and the excess blood neutrophils are presumably released from storage pools. The presence of normal numbers of GM-CFCs suggests that the multipotential stem cell compartment is unaffected. Erythropoietic impairment must, then, occur either shortly before the formation of erythroid colony forming cells or soon enough afterwards to prevent the appearance of colonies in vitro and increased erythroblast numbers in vivo.

It is tempting to conclude that impaired growth of erythroid colony forming cells underlies the anaemia in bronchial cancer. Erythroid colony forming cell suppression, however, was most noticeable in the non-anaemic group of patients; anaemic patients showed only an insignificant trend towards fewer erythroid colony forming cells. Furthermore, four of 13 anaemic patients possessed large numbers of CFU-E, and there was no correlation between erythroid colony forming cells and haemoglobin concentrations in patients with bronchial cancer. Consequently, it seems unlikely that the anaemia in all such patients could arise from poor erythroid colony forming cell growth. Tumour cell infiltration into the marrow was noted in only one patient and does not seem to have been responsible for reduced numbers of erythroid colony forming cells.

By showing significant suppression of erythroid colony forming cell growth, our data differ from published findings on mixed cancers ${ }^{6}$ and rheumatoid arthritis, ${ }^{1230}$ in which erythroid colony forming cell numbers in normal and diseased donors were similar. 
There are some methodological differences between these earlier studies and the work we report here, and these could be critical to the results.

Although none of the irregularities in blood and marrow cell populations apparently correlates with haemoglobin concentration or erythroid colony forming cell numbers in patients with bronchial cancer, a qualitative rather than a quantitative change in neutrophils, monocytes, or lymphocytes may be responsible for impaired erythropoiesis. ${ }^{12-14}$ Indeed, marrow adherent cells from anaemic patients with chronic disease have been shown to inhibit in vitro erythropoiesis. ${ }^{1331}$ Any inhibitory factor would have to act over a short range as we have been unable to corroborate a previous report ${ }^{11}$ that inhibitors of erythropoiesis circulate in bronchial cancer sera. Only one of our bronchial cancer sera proved inhibitory when added to normal marrow cultures containing $25 \%$ AB serum; most "weakly supported" erythroid colony formation. Our observation that several bronchial cancer sera "strongly supported" erythroid colony forming cell proliferation is consistent with our earlier report ${ }^{9}$ that some patients with bronchial cancer do respond to their anaemia by increasing production of erythropoietin (and perhaps other positive regulators of erythropoiesis as well).

To summarise, considerable perturbations occur in mature haemopoietic populations and in the erythroid progenitor compartments in patients with bronchial cancer, although the associations between these phenomena are obscure and their role, if any, in the onset of anaemia remains undefined. Anaemia in bronchial cancer may result from the interplay of several of these population inbalances or, alternatively, the changes reported here may be epiphenomena associated with a more fundamental haemopoietic defect.

We are indebted to Dr Salim Kaaba, Caroline Dallimore, and Margaret Booth for technical help and to Julie Spiteri for typing the manuscript.

\section{References}

1 Al-Ismail S, Cavill I, Evans IH, et al. Erythropoiesis and iron metabolism in Hodgkin's disease. Br J Cancer 1979;40:365-70.

2 Ting WC, Cavill I, Jacobs A, et al. Anaemia in patients with myelomatosis. Br J Cancer 1982;45:887-94.

3 Cavill I, Bentley DP. Erythropoiesis in the anaemia of rheumatoid arthritis. Br J Haematol 1982;50:583-90.

4 Ward HP, Kurnick JE, Pisarczyk MJ. Serum level of erythropoietin in anaemias associated with chronic infection, malignancy and primary haematopoietic disease. $J$ Clin Invest 1971;50:332-5.

5 Firat D, Banzon J. Erythropoietic effect of plasma from patients with advanced cancer. Cancer Res 1971;31:1353-8.

6 Dainiak N, Kulkarni V, Howard D. Mechanism of abnormal erythropoiesis in malignancy. Cancer 1983;51:1101-6.
7 Douglas SW, Adamson JW. The anaemia of chronic disorders: studies of marrow regulation and iron metabolism. Blood 1975;45:55-65.

8 Cotes PM, Brozovic B, Mansell M, Samson DM. Radioimmunoassay of erythropoietin (Ep) in human serum validation and application of an assay system. Exp Haematol 1980;8 (suppl 8):292.

9 Schreuder W, Ting WC, Smith S, Jacobs A. Testosterone, erythropoietin and anaemia in patients with disseminated bronchial cancer. Br J Haematol 1984;57:521-6.

10 McGonigle EJS, Boineau FG, Beckman B, et al. Erythropoietin and inhibitors of in-vitro erythropoiesis in the development of anemia in children with renal disease. J Lab Clin Med 1985; 105:449-58.

11 Kaaba SA, Schreuder WO, Ting WC, Jacobs A. Inhibition of erythroid colony growth in-vitro by serum from patients with disseminated bronchial cancer. Exp Hematol 1984;12:641-4.

12 Reid CDL, Prouse JP, Baptista LC, Gumpel JH, Chanarin I. The mechanism of the anaemia in rheumatoid arthritis: effects of bone marrow adherent cells and of serum on in-vitro erythropoiesis. Br J Haematol 1984;58:607-15.

13 Zanjani ED, McGlave PB, Davies SF, Banisadre M, Kaplan ME Sarosi GA. In-vitro suppression of erythropoiesis by bone marrow adherent cells from some patients with fungal infection. Br J Haematol 1982;50:479-90.

14 Lamperi S, Carozzi S. T lymphocytes, monocytes and erythropoiesis disorders in chronic renal failure. Nephron 1985; 39:211-5.

15 Fiorini S, Marinig C, Riboli P, et al. AIDS-like immunologic alterations in clinically unaffected drug users. Am J Clin Pathol 1985;84:354-7.

16 Castella A, Croxson TS, Mildvan D, Witt DH, Zalvsky R. The bone marrow in AIDS. A histologic, hematologic and microbiologic study. Am J Clin Pathol 1985;84:425-32.

17 Knox SJ, Greenberg BR, Anderson RW, Rosenblatt LS. Studies of T-lymphocytes in preleukaemic disorders and acute non lymphocytic leukaemia: in-vitro radiosensitivity, mitogenic responsiveness, colony formation and enumeration of lymphocytic subpopulations. Blood 1983;62:449-55.

18 Mangan KF, Zidar B, Shadduck RK, Zeigler Z, Winkelstein A. Interferon-induced aplasia: evidence for T-cell-mediated suppression of hematopoiesis and recovery after treatment with horse antihuman thymocyte globulin. Am J Hematol 1985;19:401-13.

19. Iscove NN, Sieber F, Winterhalter KH. Erythroid colony formation in cultures of mouse and human bone marrow, analysis of the requirement for erythropoietin by gel, filtration and affinity chromatography on agarose concanavalin A. J Cell Physiol 1974;83:309-20.

20 Bailey-Wood R, Dallimore CM, Smith SA, Whittaker JA. Use of logistic regression analysis to improve prediction of prognosis in acute myeloid leukaemia. Leuk Res 1984;8:667-80.

21 Burgess AW, Wilson EMA, Metcalf D. Stimulation by human placental conditioned medium of hemopoietic colony formation by human marrow cells. Blood 1977;49:573-83.

22 Daniel WW. Applied nonparametric statistics. Boston: Houghton Mifflin, 1978.

23 Bentley DP. Anaemia and chronic disease. In: Jacobs A, ed. Clinics in haematology. Toronto: WB Saunders, 1982:465-79.

24 Zucker S. Anemia in cancer. Cancer Invest 1985;3:249-60.

25 Lee GR. The anemia of chronic disease. Sem in Haematol 1983;20:61-80.

26 Bagby GC, Rigas VB, Bennet RM, Vandenbark AA, Garewol HS. Interaction of lactoferrin, monocytes and $T$ lymphocyte subsets in the regulation of steady state granulopoiesis in vitro. $J$ Clin Invest 1981;68:56-63.

27 Kouranakis LH, Manikou H, Tsougranis A. Restoration of immunosuppression in lung cancer by normal sera. J Clin Lab Immunol 1985;16:149-53.

28 Santos LB, Yamada FT, Scheinberg MA. Monocyte and lym- 
phocyte interaction in patients with advanced cancer. Evidence for deficient IL-1 production. Cancer 1985;56:1553-8.

29 Felder M, Dore CJ, Knight SC, Ansell M. In vitro stimulation of lymphocytes from patients with rheumatoid arthritis: Clin Immunol Immunopathol 1985;37:253-61.

30 Prouse PJ, Bonner B, Gumpel JM, Reid CDL. Stimulation of bone marrow erythropoiesis by $\mathrm{T}$ lymphocytes of anaemic patients with rheumatoid arthritis. Ann Rheum Dis $1985 ; 44: 220-3$.
31 Roodman GD, Horadam VW, Wright TL. Inhibition of erythroid colony formation by autologous bone marrow adherent cells from patients with the anaemia of chronic disease. Blood 1983;62:406-12.

Requests for reprints to: Dr P Baines, Department of Haematology, University Hospital of Wales, Heath Park, Cardiff CF4 4XW. 